\title{
Pendidikan Karakter Menurut Imam Nawawi dan Aplikasinya dalam Kehidupan
}

\author{
Wanty Khaira ${ }^{* 1}$, Irman Siswanto ${ }^{2}$ \\ Universitas Islam Negeri Ar-Raniry Banda Aceh ${ }^{1,2}$, \\ e-mail: ${ }^{* 1}$ wanty.khaira@ar-raniry.ac.id, 2irman.siswanto@ar-raniry.ac.id
}

\begin{abstract}
Character can be interpreted as character, character, psychological traits, morals or character that distinguishes one person from another. One of the works of Imam Nawawi ra. is the Book of Riyadhus Shalihin which is a very famous book in the Islamic world. This book has been used as a guide for years among scholars, students and students of religious knowledge in parts of the Islamic world. The contents of the work of Imam Nawawi ra. This is able to organize and grow the strength of a big soul in someone in worshiping Allah SWT, the creator of the universe, because worshiping Allah SWT can lead a person to goodness and happiness. The purpose of this study was to determine the application of character education according to Imam Nawawi ra. within the Madrasah Aliyah environment in Aceh. This study uses a qualitative method. This research was conducted by collecting the necessary library data, especially the essay of Imam Nawawi ra. Data collection also uses observations and interviews with the community in the Madrasah Aliyah environment in Aceh to obtain character education application data according to Imam Nawawi ra. The results showed that the values of character education according to Imam Nawawi ra. related to Commandments, related to Warnings and related to Instructions and character with Allah and with Creatures. For the community in the Madrasah Aliyah environment in Aceh, they have applied character education that has been formulated by Imam Nawawi ra.as the regulations that apply in the Madrasah environment.
\end{abstract}

Keywords: character building; Imam Nawawi; Application

\begin{abstract}
Abstrak
Karakter bisa diartikan sebagai tabiat, watak, sifat-sifat kejiwaan, akhlak atau budi pekerti yang membedakanseseorang dari yang lain. Salah satu karya Imam Nawawi ra. adalah Kitab Riyadhus Shalihin yang merupakan sebuah kitab yang sangat masyhur dalam dunia Islam. Kitab ini telah dijadikan pegangan bertahun-tahun di kalangan para ulama, pelajar dan penuntut ilmu agama di belahan dunia Islam. Isi kandungan karya Imam Nawawi ra. ini mampu menata dan menumbuhkan kekuatan berjiwa besar pada seseorang dalam beribadah kepada Allah
\end{abstract}


SWT pencipta alam semesta, karena dengan beribadah kepada Allah SWT dapat mengantar seseorang kepada kebaikan dan kebahagiaan. Tujuan penelitian ini adalah untuk mengetahui aplikasi pendidikan karakter menurut Imam Nawawi ra. dalam lingkungan Madrasah Aliyah di Aceh. Penelitian ini menggunakan metode kualitatif. Penelitian ini dilakukan dengan mengumpulkan data-data kepustakaan yang diperlukan, terutama karangan Imam Nawawi ra. Pengumpulan data juga menggunakan observasi dan wawancara dengan masyarakat di lingkungan Madrasah Aliyah di Aceh untuk mendapatkan data aplikasi pendidikan karakter menurut Imam Nawawi ra. Hasil penelitian menunjukkan bahwa nilai-nilai pendidikan karakter menurut Imam Nawawi ra. berkaitan dengan Perintah, berkaitan dengan Peringatan dan berkaitan dengan Petunjuk serta karakter dengan Allah dan dengan Makhluk. Bagi masyarakat di lingkungan Madrasah Aliyah di Aceh telah mengaplikasikan pendidikan karakter yang telah dirumuskan oleh Imam Nawawi ra.sebagai peraturanyang berlaku di lingkunganMadrasah.

Kata Kunci: pendidikan Karakter; Imam Nawawi; Aplikasi

\section{PENDAHULUAN}

Pendidikan karakter sudah menjadi 'trending topic' dalam dunia pendidikan akhir-akhir ini. Hal itu muncul setelah gagasan pendidikan karakter yang digaungkan pemerintah dalam perubahan kurikulum tahun 2013. Keberadaannya haruslah memiliki arah dan tujuannya yang jelas. Sehingga implementasi di lapangan menjadi mudah dilaksanakan.

Karakter bisa diartikan sebagai tabiat, watak, sifat-sifat kejiwaan, akhlak atau budi pekerti yang membedakan seseorang dari yang lain (Farida, 2016; Haris, 2017; Sajadi, 2019). Akhlak merupakan suatu perilaku yang baik yang dilakukan oleh manusia sehingga menjadi sebuah kebiasaan yang di amalkan dalam kehidupan sehari-hari.

Allah SWT mengutus Rasulullah kemuka bumi ini adalah sebagai rahmat bagi umat manusia dalam penyempurnaan akhlak mereka. Ini menunjukkan bahwa pendidikan akhlak dalam kehidupan sangatlah diperlukan. Banyak sumber-sumber pendidikan akhlak yang dapat digunakan sebagai bahan ataupun rujukan. Bila dilihat dari pengarangnya, yang mengkaji tentang Akhlak banyak sekali, namun dalam penelitian ini peneliti hanya mengkaji salah satunya, yaitu Imam Nawawi. 
Salah satu Kitab karangan Imam Nawawi ra. adalah Riyadhus Shalihin yang merupakan sebuah kitab yang sangat masyhur dalam dunia Islam (Ihsan, 2020). Kitab ini telah dijadikan pegangan bertahun-tahun di kalangan para ulama, pelajar dan penuntut ilmu agama di belahan dunia Islam. Kitab Riyadhus Shalihin ini diartikan sebagai pelatihan orang-orang shalih, dibahas menjadi 372 Bab dengan jumlah hadis sebanyak 1900 hadis. Metode penulisan hadis oleh Imam Nawawi mengemukakan ayat-ayat al-Qurean sebagai dalil utama untuk menguatkan dalil-dalil hadis yang dibahas, untuk lebih jelas dan konkrit jabaran atas hal-hal yang perlu dibahas.

Kitab Riyadhus Shalihin karangan Imam Nawawi ra. Ini sungguh memiliki keistimewaan yang tidak berbeda dari kitab-kitab sunnah lainnya. Kitab Riyadhus Shalihin ini benar-benar menjadi bekal dan modal bagi penasihat, penceramah, dan pembimbing agama terhadap masyarakat Islam. Hal inilah yang menjadi sebab kitab Riyadhus Shalihin ini mendapat kedudukan yang tinggi dalam pandangan ulama sehingga mereka memberikan syarah, komentar dan mengajarkannya di halaqah-halaqah pembelajaran agama bagi masyarakat.

Isi kandungan kitab Riyadhus Shalihin karangan Imam Nawawi ra. ini mampu menata dan menumbuhkan kekuatan berjiwa besar pada seseorang dalam beribadah kepada Allah SWT pencipta alam semesta. Karena dengan beribadah kepada Allah SWT dapat mengantar seseorang kepada kebaikan dan kebahagiaan. Kitab ini umumnya meliputi kebutuhan orang-orang muslim yang berkaitan dengan agama, dunia dan akhirat kelak. Kitab Riyadhus Shalihin adalah kitab tarbiyah (pendidikan, pembinaan) dalam segala aneka ragam aspek kehidupan individual (pribadi), sosial kemasyarakatan yang mudah, jelas, dan dapat dipahami oleh orang-orang khusus dan orang-orang awam.

Pembahasan isi dari kitab Riyadhus Shalihin ini diawali dengan tema ikhlas dan niat dalam segala perilaku kehidupan. Imam Nawawi membuka kitab Riyadhus Shalihin itu dengan menyertakan ayat-ayat Qurean yang mendukung tentang pembahasan tema ikhlas dan niat menurut Islam. Seluruh isi kitab Riyadhus Shalihin ini mengandung ruh (kekuatan) pendorong seseorang untuk menghambakan diri kepada Allah serta memupuk amal shalih. Isi kitab Riyadhus Shalihin ini tidak luput berbicara mengenai masalah hati dan kebersihan jiwa. Termasuk masalah ikhlas, niat, taubat, sabar, shiddiq, muraqabah, yaqin, tawakal, istiqamah, mujahadah, hemat, rajin, zuhud, qana"ah, 
dermawan, tolong menolong, nasehat, amar ma"ruf nahi mungkar, amanat, dan menghindari kezaliman.

Kandungan kitab Riyadhus Shalihin karangan Imam Nawawi ra. sangat sarat dengan pendidikan karakter yang dibutuhkan oleh manusia dalam kehidupan sehari-hari, dalam memperoleh kebahagiaan hidup baik di dunia maupun di akhirat kelak. Hal inilah yang mendorong penulis meneliti, menelaah, dan mengulas isi kandungan kitab Riyadhush Shalihin secara khusus yang berkaitan dengan pendidikan akhlak serta kajian ini melihat implementasi dalam kehidupan masyarakat Aceh.

Kitab al-Arba'in al-Nawawiyah merupakan kitab kumpulan hadist yang sangat terkenal karya Imam Abu Zakariya Yahya bin Asyraf An-Nawawi(AnNawawi, 2007), yang selanjutnya lebih dikenal dengan nama Hadist Arbain Nawawi. Penyebutan nama kitab ini berdasarkan jumlah hadist yang terhimpun ada 40-an.

Imam Nawawi telah menyusun kitab hadist arba'in yang sangat populer dan masyhur dikalangan umat Islam, sehingga dijadikan salah satu rujukan dan kurikulum yang harus dikuasai dan dipahami dan bahkan dihafal oleh para siswa/siswi madrasah dan santriwan/santriwati pada berbagai jenjang dalam lembaga pendidikan yang ada di Indonesia.

Mengenai kitab arba"in, Imam Nawawi sendiri telah menegaskan bahwa amatlah patut bagi mereka yang ingin pahala akhirat supaya mengetahui hadisthadist ini, karena kandungannya yang meliputi perkara-perkara yang penting dan berisi peringatan dalam segala urusan ketaatan.

\section{LANDASAN TEORI DAN HIPOTESIS}

Pada bagian ini, secara jelas dan ringkas diuraikan teori-teori dan atau konsep yang dijadikan sebagai landasan dalam mengkaji masalah penelitian, dan hipotesis bila kajian yang dilakukan berbentuk penelitian kuantitatif. Di dalamnya juga dimuat secara integral kajian terdahulu berupa hasil-hasil penelitian yang hampir sama. Imam an-Nawawi rahimahullah, lahir pada tanggal 10 Muharram $631 \mathrm{H}$ di Nawa (sebuah desa di wilayah Syam, tepatnya bagian dari kawasan Damaskus). Nama lengkapnya adalah Syekh Imam „Allaamah (ulama besar) Muhyiddin Abu Zakaria Yahya bin Syaraf bin Murry bin Hasan bin Husain bin Hizam bin Muhammad bin Jum"ah an-Nawawi asySyafiei. Beliau dididik oleh ayah beliau yang terkenal dengan kesalehan dan 
ketakwaan. Beliau mulai belajar di Katatib (tempat belajar baca tulis untuk anakanak) dan hafal Al-Qur'an sebelum menginjak usia baligh.

Dalam diri Imam Nawawi tercermin sifat-sifat alim, suka memberi nasehat, seorang yang berjihad di jalan Allah dengan lisannya, menegakkan kewajiban beramar ma"eruf nahi mungkar. Seorang yang mukhlish dalam memberi nasehat, tidak mempunyai tendensi apapun, seorang yang pemberani, tidak takut celaan di jalan Allah terhadap orang yang mencelanya. Seorang yang mempunyai bayan dan hujjah untuk memperkuat dakwaannya. Beliau dijadikan rujukan oleh manusia bila mereka menghadapi perkara yang sulit dan pelik, serta minta fatwa kepadanya, dan Beliau menanggapinya serta berusaha memecahkan permasalahannya.

Semasa hidupnya Imam an-Nawawi (2005) telah melahirkan banyak karya, baik dalam bidang ilmu hadits maupun dalam bidang ilmu fiqih yang manfaatnya telah dapat dirasakan oleh jutaan kaum muslimin di seluruh penjuru dunia hingga sekarang. Riyadhus Shalihin merupakan kitab karangan Imam Nawawi ra., kitab kumpulan hadits Rasulullah Saw berkenaan dengan berbagai persoalan. Kitab ini disusun oleh al-Imam al-Allamah Abu Zakaria Muhyiddin bin Syaraf an-Nawawi ad-Dimasyqi yang lebih dikenal dengan sebutan Imam Nawawi. Seorang ulama besar Ahli hadits yang diakui seluruh ulama Islam dari masa ke masa. Pada kitab ini hadits- hadits Rasulullah Saw dikelompokkan ke dalam beberapa bab berdasarkan tema-tema utama, shalat, zakat, jihad, doa, dan Qurean. Sangat cocok menjadi pegangan muslim yang ingin mempelajari sunah- sunah Rasulullah Saw.

Dalam kitab Riyadhus Shalihin karangan Imam Nawawi ra. dihimpunkan hadits-hadits shahih secara singkat padat, mencakup semua aspek pendidikan yang merintis jalan ke surga, sebagai pembimbing tata hidup jasmani dan rohani, sumber pembangkit amal baik peringatan, latihan jiwa, pendidikan akhlak mulia, obat penyembuh mental dan penjaga fisik. Yang dikutip dari hadits-hadits shahih yang tidak perlu diragukan dan dihubungkan pula dengan sumber pertama dan utamanya (yakni) ayat-ayat al-Qurean serta komentar dari pengarang ala kadarnya.

Kitab Riyadhus Shalihin karangan Imam Nawawi ra. ini diartikan sebagai "pelatihan orang-orang shalih", dibahas menjadi 372 Bab dengan jumlah hadis sebanyak 1900 hadis. Metode penulisan hadis oleh Imam Nawawi mengemukakan ayat-ayat al-Qurean sebagai dalil utama untuk menguatkan 
dalil-dalil hadis yang dibahas, untuk lebih jelas dan konkrit jabaran atas hal-hal yang perlu dibahas.

Di dalam mukaddimah kitabnya, Imam Nawawi mengatakan bahwa kitabnya itu mengandung hadis-hadis yang beliau kutip dari Kutubussittah (enam kitab utama), yaitu kitab hadis yang paling utama dalam Islam, dan secara tegas dikatakan bahwa beliau hanya mengutip hadis-hadis yang shahih dari kitab-kitab yang masyhur itu.

Kitab Riyadhus Shalihin karangan Imam Nawawi ra. ini sungguh memiliki keistimewaan yang tidak berbeda dari kitab-kitab Sunnah lainnya. Kitab Riyadhus Shalihin ini benar-benar menjadi bekal dan modal bagi penasihat, penceramah, dan pembimbing agama terhadap masyarakat Islam. Hal inilah yang menjadi sebab kitab Riyadhus Shalihin ini mendapat kedudukan yang tinggi dalam pandangan ulama sehingga mereka memberikan syarah, komentar dan mengajarkannya di halaqah- halaqah pembelajaran agama bagi masyarakat. Sebab kitab Riyadhush Shalihin mempunyai dua kandungan yaitu Targhib dan Tarhib.

Kata targhib diambil dari kata kerja - رغب برغب - ترغيبا secara etimologis yang berarti : menyenangi, menyukai dan mencintai. Kata itu dalam pembahasan ini diambil pada kata benda targhib yang mengandung maknanya : suatu harapan utuk memperoleh kesenangan, kecintaan, kebahagiaan.

Semua pengertian itu memotivasi terhadap perolehan berupa keindahan dan kebahagiaan yang dapat menjadi sarana dalam kehidupan seseorang. Secara psikologis, melalui pola targhib merupakan cara untuk menimbulkan daya tarik yang kuat dalam menggapainya.

رهب - برهب - ترهيب Sementara istilah tarhib berasal dari kata yang mempunyai arti menakut- nakuti atau mengancam. Lalu dalam pembahasan ini dipakai kata benda yaitu tarhib artinya ancaman, hukuman (Syahidin, 1999).

Dari pengertian diatas dapat dipahami bahwa yang dimaksud dengan targhib adalah janji yang membuat rasa senang, terhadap suatu yang maslahat, kenikmatan atau kebahagiaan baik dunia maupun akhirat kelak. Sementara tarhib adalah suatu ancaman atau siksaan sebagai akibat dari megerjakan hal yang negative yang dapat mendatangkan dosa atau kesalahan yang dilarang oleh Allah SWT. Isi kandungan kitab Riyadhus Shalihin adalah bimbingan yang dapat menata jiwa serta melahirkan satu kekuatan yang besar bagi seseorang 
dalam beribadah yang sesuai dengan tujuan diciptakan manusia oleh Allah SWT. Kitab ini menjadi kitab tarbiyah (pendidikan, pembinaan) yang baik yang menyentuh dua aspek kehidupan, yaitu kehidupan individual (pribadi) dan sosial (kemasyarakatan), atau kehidupan duniawi dan ukhrawi.

\section{Kajian Penelitian Terdahulu}

Kajian Penelitian yang relevan penting untuk disajikan sebagai bahan autokritik terhadap penelitian yang sedang dilakukan. Selain itu juga sebagai bahan pertimbangan dan untuk mengetahui kekurangan dan kelebihan masing-masing. Tidak kalah penting dari hal tersebut adalah untuk menghindari terjadinya pengulangan hasil temuan yang membahas permasalahan yang sama atau hampir sama dari seseorang, baik berupa jurnal ataupun bentuk tulisan lainnya. Sepanjang penelaahan penulis kajian terkait nilai-nilai pendidikan karakter yang terkandung dalam kitab Riyadhus Shalihin, berikut uraiannya:

Penelitian yang dilakukan oleh Sudrajat, (2011) dengan judul “Mengapa Pendidikan Karakter?" yang di terbitkan pada Jurnal Pendidikan Karakter, Volume 1 Nomor 1. Menyebutkan bahwa sudah menjadi kesadaran bersama bahwa dunia pendidikan merupakan cara yang telah dilakukan umat manusia sepanjang kehidupannya untuk menjadi sarana dalam melakukan transmisi dan transformasi baik nilai maupun ilmu pengetahuan. Demikian strategisnya dunia pendidikan sebagai sarana transmisi dan transformasi nilai dan ilmu pengetahuan ini, maka dalam rangka menanamkan dan mengembangkan karakter bangsa ini, tidak lepas pula dari peran yang dimainkan oleh dunia pendidikan. Pendidikan karakter penting bagi kehidupan manusia, maka peran yang dimainkan dunia pendidikan haruslah tidak sekadar menunjukkan pengetahuan moral, tetapi juga mencintai dan mau melakukan tidakan moral (Hasan, 2012; Rachmadyanti, 2017).

Penelitian lain dilakukan oleh Farida, (2016) Dengan judul "Pendidikan karakter dalam prespektif Islam." Yang diterbitkan pada jurnal KABILAH: Journal of Social Community, Volume 1 Nomor 1. Pendidikan karakter dimaknai sebagai pendidikan nilai, budi pekerti, pendidikan moral, pendidikan watak yang tujuannya untuk mengembangkan kemampuan peserta didik untuk memberikan keputusan baik buruk, mewujudkan kebaikan dalam kehidupan sehari-hari dengan sepenuh hati sebagai cita-cita luhur dalam dunia pendidikan. Oleh sebab itu, maka pendidikan karakter akan terlaksana jika selaras dengan 
sistem pendidikan nasional. Penyelengaraan pendidikan sistem pendidikan disebuah negara akan berbeda dengan negara lainnya, karena sistem pendidikan yang diselenggarakan diberbagai negara mempunyai ciri yang sesuai dengan latar belakang budaya masing-masing negara. Dalam pendidikan karakter harus melibatkan aspek seperti: kognitif, afektif, konatif, dan psikomotorik yang harus dikembangkan sebagai suatu keutuhan (holistik) dalam konteks kultural. Dalam pendidikan Islam, pendidikan karakter merupakan pendidikan yang telah diajarkan al-Qur'an, yaitu pendidikan yang mengedepankan Akhlak (Ainiyah \& Wibawa, 2013; Purnamasari, 2017; Sukatin, 2018). Al-Qur'an dengan sangat tegas memberikan solusi yang nyata kepada kita untuk mengembangkan kesadaran spiritual, emosional, dan intelektual yang tidak hanya menjadi teori, tetapi al Qur'an memerintahkan untuk menerjemahkannya dalam kehidupan sehari-hari. Kata Kunci: Pendidikan Karakter, pendidikan Islam. Pendidikan Karakter Dalam Prespektif Islam

Selanjutnya ada buku yang ditulis oleh Sani \& Kadri (2016) Pendidikan Karakter: Mengembangkan Karakter Anak yang Islami. Buku ini membahas tentang strategi dan metode yang dapat digunakan untuk mengembangkan karakter anak. Kajian dilakukan berdasarkan Alquran dan sunah Rasullah, serta dipadukan dnegan ilmu pendidikan modern. Upaya mendidik anak merupakan hal yang pembahasannya sangat penting dalam ajaran Islam. Buku ini dibagi dalam enam bab yang mencakup konsep pendidikan karakter, atribut karakter berdasarkan Alquran dan hadits, strategi dan metode pendidikan karakter di rumah, hal penting yang harus diajarkan kepada anak, serta wawasan untuk menghadapi upaya pendangkalan akidah oleh nonmuslim.

Penelitian ini berbeda dengan penelitian sebelumnya, karena pada penelitian ini menjadikan kitab Riyadhus Shalihin sebagai standar pendidikan karakter dan implikasinya dalam kehidupan masyarakat Aceh.

\section{METODE PENELITIAN}

Penelitian ini menggunakan penelitian kualtitatif. Menurut Moleong, (2011) "penelitian kualitatif adalah penelitian yang bermaksud untuk memahami fenomena tentang apa yang dialami oleh subjek penelitian misalnya prilaku, persepsi, motivasi, tindakan, dll., secara holistik dan dengan cara deskripsi dalam bentuk kata-kata dan bahasa, pada suatu konteks khusus yang alamiah dan dengan memanfaatkan berbaai metode alamiah. Penelitian ini menggunakan 
metode kualitatif. Penelitian ini dilakukan dengan mengumpulkan data-data kepustakaan yang diperlukan, terutama karangan Imam Nawawi ra. diantaranya dari kitab Riyadhus Shalihin, kitab al-Arba'in al-Nawawiyah dan dari buku- buku yang berkaitan dengan tema penelitian tentang pendidikan karakter. Dari data-data yang terkumpul akan dibahas dengan metode deskriptif analitis, yaitu metode pembahasan masalah dengan cara memaparkan atau menguraikan pokok masalah secara teoritis, untuk kemudian menganalisisnya dalam rangka mendapatkan sesuatu kesimpulan yang tepat. Metode Penelitian (bisa meliputi analisa, metode yang dipakai untuk menyelesaikan masalah, implementasi).

\section{HASIL DAN PEMBAHASAN}

Dalam kehidupan di lingkungan Madrasah Aliyah di Aceh, pendidikan karakter yang dibangun oleh Imam An-Nawawi khususnya yang ada dalam Kitab Riyadhus Shalihin dan kitab al-Arba'in al-Nawawiyah. Berikut Aplikatif Pendidikan Karakter berdasarkan Kitab Riyadhus Shalihin dalam Kehidupan Masyarakat di Lingkungan Madrasah Aliyah di Aceh.

\section{Aplikasi Pendidikan Karakter berkaitan dengan Perintah}

Masyarakat Madrasah Aliyah di Aceh merupakan penegak kebenaran ataupun amar ma'ruf nahi mungkar, karena semua masyarakat di lingkungan Madrasah Aliyah di Aceh adalah kaum muslimin (Mardhiah, 2020; Rahmayani, 2021). Umat muslim berfungsi sebagai penyeru kebaikan dan pencegah kemungkaran. Kemungkaran itu jangan didiamkan saja merajalela. Bila kuasa harus diperingatkan dengan perbuatan agar terhenti kemungkaran tadi seketika itu juga. Bila tidak sanggup, maka dengan lisan (dengan nasihat peringatan atau perkataan yang sopan-santun), sekalipun ini agak lambat berubahnya. Tetapi kalau masih juga tidak sanggup, maka cukuplah bahwa hati kita tidak ikut-ikut menyetujui adanya kemungkaran itu. Hanya saja yang terakhir ini adalah suatu tanda bahwa iman kita sangat lemah sekali. Karena dengan hati itu hanya bermanfaat untuk diri kita sendiri, sedang dengan perbuatan atau nasihat itu dapat bermanfaat untuk kita dan masyarakat umum, hingga kemungkaran itu tidak terus menjadi-jadi. Hal ini dilakukan atau di aplikasikan dalam lingkungan Madrasah Aliyah di Aceh. 


\section{Aplikasi Pendidikan Karakter berkaitan dengan Peringatan Bagi masyarakat Madrasah Aliyah di Aceh}

Manakala di dalam suatu tempat atau negeri sudah terlampau banyak keburukan, kemungkaran, kefasikan dan kecurangan, maka kebinasaan dan kerusakan akan merata di daerah itu dan tidak hanya mengenai orang jahat-jahat saja, tetapi orang-orang shalih tidak akan dapat menghindarkan diri dari azab Allah itu sekalipun jumlah mereka itu cukup banyak. Oleh sebab itu segala macam kemaksiatan dan kemungkaran hendaklah segera dibasmi dan segala keburukan segera dimusnahkan.

Ada berbagai cara dan bentuk pemusnahannya diantaranya membina dan meminta kepada pelaku untuk melaksanakan salat taubat, dalam proses taubat, diperlukan sebuah pengorbanan untuk menyesali secara mendalam perbuatan dosa yang telah kita lakukan.

\section{Nilai Pendidikan karakter berkaitan dengan Petunjuk Masyarakat Madrasah}

\section{Aliyah di Aceh}

Taubat bukan hanya sebuah literal yang diucapkan secara verbal di dalam hati, tetapi juga diperlukan sebuah kesungguhan hati dan perbuatan. Kemudian yang paling utama, niat taubat dari diri kita benar-benar murni hanya untuk mendapat ampunan dari Allah semata.

Hijrah adalah manifestasi taubat nashuha. Dengan hijrah hidup fitrah dimulai, praktek-praktek amal shaleh didukung dan para pelanggarnya ditindak dengan hukum Allah yang universal ditegakkan. Niat ikhlas adalah syarat pokok semua ibadah yang diterima disisi Allah SWT. tidak dikatakan seseorangf melakukan taubat yang nashuha bila telah rusak niatnya. Berniat yang bersungguh-sungguh tidak akan mengulangi maksiat yang pernah dia lakukan.

Setiap nilai pendidikan yang terkandung dalam kitab riyadhussalihin telah di aplikasikan dalam lingkungan Madrasah Aliyah di Aceh. ada yang langsung dilakukan dilapangan dan juga diterapkan dalam merumuskan peraturan Madrasah.

Berikut ini disampaikan aplikatif pendidikan karakter berdasarkan kitab al-Arba'in al-Nawawiyah dalam Kehidupan Masyarakat di Lingkungan Madrasah Aliyah di Aceh 
1. Nilai-Nilai Akhlak Kepada Allah: Adapun unsur nilai karakter kepada Allah adalah Ketauhidan, Takwa, Doa, Malu, dan Tawakkal

2. Akhlak Kepada Makhluk: Akhlak Kepada Makhluk terdiri dari Akhlak kepada sesama. Adapun unsur nilai karakter Kepada Makhluk adalah Berkata Baik, Dermawan Menahan Amarah, Menjaga Kehormatan, Nasihat, Persaudaraan, Penolong, dan Pemaaf.

3. Akhlak Terhadap Diri Sendiri memlik unsur-unsur memelihara Kebersihan dan Keindahan, dan Zuhud.

4. Akhlak terhadap Tetangga dan Tamu adalah menghromati tetangga. Sedangkan Akhlak terhadap Binatang terdiri dari menyayangi binatang.

Setiap karakter menurut imam nawawi dalam karyanya kitab al-Arba'in al-Nawawiyah berdasarkan observasi dan wawancara dengan warga madrasah semua telah dilakukan dengan baik.

Pendidikan Karakter menurut Imam Nawawi berdasarkan Kitab Riyadhus Shalihin dan kitab al-Arba'in al-Nawawiyah dalam Kehidupan Masyarakat di Lingkungan Madrasah Aliyah di Aceh adalah dilakukan dengan baik di Lingkungan Madrasah Aliyah di Aceh. Baik aplikasi Pendidikan Karakter berkaitan dengan Perintah, aplikasi Pendidikan Karakter berkaitan dengan Peringatan, maupun Nilai Pendidikan karakter berkaitan dengan Petunjuk berdasarkan kitab Riyadhus Shalihin.

Begitu juga aplikatif pendidikan karakter berdasarkan kitab al-Arba'in alNawawiyah dalam Kehidupan Masyarakat di Lingkungan Madrasah Aliyah di Aceh juga telah dilakukan dengan baik, baik nilai-nilai akhlak kepada Allah (ketauhidan, takwa, doa, malu, dan tawakkal), maupun akhlak kepada makhluk.

Aplikasi dilakukan melalui pelaksanaan pembelajaran pendidikan Agama Islam. Setiap karakter menurut imam nawawi dalam karyanya kitab alArba'in al-Nawawiyah berdasarkan observasi dan wawancara dengan warga madrasah semua telah dilakukan dengan baik. Yaitu melalui penanaman akhlak melalui mau'izah (Nasihat), penanaman akhlak melalui uswatun hasanah (Keteladanan), penenaman akhlak melalui pembiasaan, penanaman akhlak melalui Targhib dan Tarhib. 


\section{KESIMPULAN}

Penelitian ini telah menemukan sebuah kesimpulan bahwa nilai-nilai pendidikan karakter menurut Imam Nawawi ra. adalah berdasarkan Kitab Riyadhus Shalihin dan kitab al-Arba'in al-Nawawiyah. berdasarkan Kitab Riyadhus Shalihin nilai-nilai pendidikan karakter berkaitan dengan perintah, peringatan dan petunjuk. Bagi masyarakat di lingkungan Madrasah Aliyah di Aceh telah mengaplikasikan pendidikan karakter yang telah dirumuskan oleh Imam Nawawi ra. sebagai peraturan yang berlaku di lingkungan Madrasah. Berdasarkan Kitab al-Arba'in al- Nawawiyah baik nilainilai akhlak kepada Allah (ketauhidan, takwa, doa, malu, dan tawakkal), maupun akhlak kepada makhluk.

Aplikasi dilakukan melalui pelaksanaan pembelajaran pendidikan Agama Islam. Setiap karakter menurut imam nawawi dalam karyanya kitab alArba'in al-Nawawiyah berdasarkan observasi dan wawancara dengan warga madrasah semua telah dilakukan dengan baik. Yaitu melalui penanaman akhlak melalui mau'izah (Nasihat), penanaman akhlak melalui uswatun hasanah (Keteladanan), penenaman akhlak melalui pembiasaan, penanaman akhlak melalui Targhib dan Tarhib. 


\section{DAFTAR PUSTAKA}

Ainiyah, N., \& Wibawa, N. H. H. P. (2013). Pembentukan Karakter Melalui Pendidikan Agama Islam. Al-Ulum, 13(1), 25-38. https://www.journal.iaingorontalo.ac.id/index.php/au/article/view/179.

An-Nawawi, A. Z. Y. bin S. (2007). Riyadhush Shalihin. Dar Ibni Katsir.

Farida, S. (2016). Pendidikan karakter dalam prespektif Islam. KABILAH : Journal of Social Community, 1(1), 198-207. http://ejournal.kopertais4.or.id/madura/index.php/kabilah/article/view/17 24

Haris, A. H. (2017). Pendidikan Karakter dalam Perspektif Islam. AlMunawwarah: Jurnal Pendidikan Islam, 9(1), 64-82. http://ejournal.kopertais4.or.id/sasambo/index.php/munawwarah/article/ view/3296.

Hasan, S. H. (2012). Pendidikan Sejarah Untuk Memperkuat Pendidikan Karakter. Paramita: Historical Studies Journal, 22(1), Article 1. https://doi.org/10.15294/paramita.v22i1.1875

Ihsan, M. N. (2020). Studi Korelasi BAB "Yakin Dan Tawakal" Dalam Kitab "Riyadhus Sholihin" Dengan Tauhid Uluhiyah. Al-Majaalis : Jurnal Dirasat Islamiyah, 8(1), 179-221. https://doi.org/10.37397/almajaalis.v8i1.151

Imam an-Nawawi. (2005). Riyadhus Shalihin, Terj. Asep Sobari. Bening Publishing.

Mardhiah, A. (2020). Implementasi Pendidikan Damai: Di Madrasah Aliyah Negeri Rukoh Kota Banda Aceh [Post Garduated, Sekolah Pascasarjana UIN Syarif Hidayatullah Jakarta]. https://repository.uinjkt.ac.id/dspace/handle/123456789/52904

Moleong, L. J. (2011). Metodologi Penelitian Kualitatif. PT Remaja Rosdakarya.

Purnamasari, D. (2017). Pendidikan Karakter Berbasis Al-Quran. Islamic Counseling: Jurnal Bimbingan Dan Konseling Islam, 1(1), 1-24. https://doi.org/10.29240/jbk.v1i1.233

Rachmadyanti, P. (2017). Penguatan Pendidikan Karakter Bagi Siswa Sekolah Dasar Melalui Kearifan Lokal. JPsd (Jurnal Pendidikan Sekolah Dasar), 3(2), 201-214. https://doi.org/10.30870/jpsd.v3i2.2140

Rahmayani, F. (2021). Pelaksanaan Program Pembinaan Akhlak Oleh Wilayatul Hisbah di Kota Langsa. Kumpulan Karya Ilmiah Mahasiswa Fakultas Agama 
Islam Dan Humaniora, 2(02), 17-17. https://jurnal.pancabudi.ac.id/index.php/Faihu/article/view/1948.

Sajadi, D. (2019). Pendidikan Karakter Dalam Perspektif Islam. Tahdzib Al-Akhlaq: Jurnal Pendidikan Islam, 2(2), 16-34. https://doi.org/10.34005/tahdzib.v2i2.510

Sani, R. A., \& Kadri, M. (2016). Pendidikan Karakter: Mengembangkan Karakter Anak yang Islami. Bumi Aksara. https://books.google.co.id/books?id=Vq_xDwAAQBAJ

Sudrajat, A. (2011). Mengapa Pendidikan Karakter? Jurnal Pendidikan Karakter, 1(1), Article 1. https://doi.org/10.21831/jpk.v1i1.1316

Sukatin, S. (2018). Pendidikan Karakter Dalam Prespektif Islam. NUR EL-ISLAM: Jurnal Pendidikan dan Sosial Keagamaan, 5(2), 131-149. https://doi.org/10.51311/nuris.v5i2.111

Syahidin. (1999). Metode Pendidikan Qur"ani Teori dan Aflikasi. Misaka Galiza. 